\title{
Effect of feeding silages from different plant raw materials on the profile of fatty acids, cholesterol, and vitamins $A$ and $E$ in lamb meat
}

\author{
Stanisław Milewski ${ }^{1}$, Cezary Purwin ${ }^{2}$, Barbara Pysera ${ }^{2}$, Krzysztof Lipiński $^{2}$, \\ Zofia Antoszkiewicz ${ }^{2}$, Przemysław Sobiech ${ }^{3}$, Katarzyna Ząbek $^{1}$, Maja Fijałkowska ${ }^{2}$, \\ Zenon Tański ${ }^{1}$, Josef Illek ${ }^{4}$ \\ ${ }^{1}$ University of Warmia and Mazury in Olsztyn, Faculty of Bioengineering, Department of Sheep and Goat \\ Breeding, ${ }^{2}$ Department of Animal Nutrition and Feed Management, ${ }^{3}$ Faculty of Veterinary Medicine \\ Department of Internal Diseases, Olsztyn, Poland \\ ${ }^{4}$ University of Veterinary and Pharmaceutical Sciences, Faculty of Veterinary Medicine, \\ Clinic of Ruminant Diseases, Brno, Czech Republic \\ Received December 1, 2013 \\ Accepted July 23, 2014
}

\begin{abstract}
Recently, the quality of lamb meat has been regarded with attention to the content of intramuscular fat, and its fatty acid profile. These indicators are determined by the feed administered to the animals. Apparently, the type of silage used in animal nutrition may be important. The objective of this study was to determine the effect of feeding lambs with silages produced from different plant species on selected meat quality traits. The experiment was conducted on 24 ram lambs, divided into 3 equal groups fed with red clover silage, alfalfa silage, and grass silage, respectively. After 60 days of fattening, the lambs were slaughtered. Samples collected from musculus longissimus lumborum were assayed for: contents of intramuscular fat, cholesterol, the vitamins retinol and $\alpha$-tocopherol, and the fatty acid profile of intramuscular fat. The meat of lambs fed red clover silage was characterized by a higher content of fat compared to lambs receiving grass silage $(P \leq 0.05)$. The concentration of vitamin $\mathrm{E}$ in the group fed grass silage was the highest and differed significantly $(P \leq 0.01)$ compared to the group fed alfalfa silage. Intramuscular fat of lambs fed red clover silage contained more polyunsaturated fatty acids $n-3$ and was characterized by a lower ratio of polyunsaturated fatty acids n-6:n-3 compared to the lambs fed grass silage. The concentration of conjugated linoleic acid was higher in lambs fed grass silage compared to fat of lambs from the other groups $(P \leq 0.05)$. Feeding lambs with silages produced from various plant species had a positive effect on traits characterizing the health quality of meat. Until now, only a few studies have been conducted in this species; this is the first such comprehensive study in sheep.
\end{abstract}

Silage, lambs, quality of meat, atherogenic index, thrombogenic index

The high quality and health-promoting properties of lamb meat determine it to be a valuable food product. A key factor affecting the health quality of lamb meat is the feeding of lambs (Ząbek et al. 2013). Very often, the basic component of the lambs' diet in the winter season is silage. It is mainly ensilaged from grasses or, alternatively, their mixes with papilionaceous plants as well as from monocultures of papilionaceous plants, including alfalfa or red clover. The type of silage administered to animals may influence the quality of their end products. Lourenço et al. (2008) pinpointed the dependency of the fatty acid profile in milk and meat on the type of silage used in cattle and sheep feeding. This mechanism consists in the modification of metabolic processes in the rumen, leading to substantial changes in the fatty acid composition of milk fat or intramuscular fat. A key role in this respect may be ascribed to red clover which is likely to exhibit a strong capacity to stimulate changes in the fatty acid profile owing to, among other things, a high content of polyphenolic oxidase (PPO) that inhibits lipolysis (Dewhurst et al. 2003). Studies have shown that inclusion of red clover into the lambs' diet in the form of both green forage (Fraser et al. 2004) and silage (Lourenco et al. 2007) had a beneficial effect on the fatty 
acid profile in intramuscular fat, as it increased the contribution of polyunsaturated fatty acids (PUFA) in this fat, including that of conjugated linoleic acid (CLA) cis-9, trans-11 being of high importance in terms of health. Research done by Lourenço et al. (2007) suggests that feeding lambs with different silages induces changes in fatty acids metabolism in the rumen that may derive from differences in the extent of PUFAs biohydrogenation. This substantiates the necessity of including silages made of different plant species into lambs' feeds. In consequence, different production effects of lambs may be expected, including also the quality of their meat.

In view of the above, the aim of this study was to compare selected traits characterizing the health quality of meat of lambs fed silages produced from red clover, alfalfa or grass.

\section{Materials and Methods}

The experimental materials were 24 single ram lambs of the Polish Longwool Sheep variety Kamieniecka, weaned at the age of 70 days. They were divided into 3 equal groups ( 8 lambs per group) that were fed ad libitum experimental silages prepared from the second cut of red clover (RC), alfalfa (ALF), or grass (Festuca rubra) (GR). The initial mean body weights of lambs were comparable in all groups: RC $-22.63 \pm 0.92, \mathrm{ALF}-22.63 \pm$ $1.30, \mathrm{GR}-22.71 \pm 1.11 \mathrm{~kg}$. Apart from the silages, the lambs were administered barley meal and premix, at daily doses of $0.5 \mathrm{~kg}$ and $12.5 \mathrm{~g} / \mathrm{lamb}$, respectively. The specific fattening period spanned for 60 days. Digestibility of dry organic matter (DOMD), ether extract and crude fibre of silage were determined in vivo by the balance method, before fattening. All animals were placed in metabolic cages, and were fed only experimental silages ad libitum. After a 10-day adaptation period, the amount of administered feed was recorded; refusals and faecal samples were collected for five days (digestibility studies).

Contents of basic nutrients in samples of feeds, refusals and faeces were determined using standard methods

Table 1. Chemical composition, characteristic of fermentation and intake of silages $\left(\mathrm{g} \cdot \mathrm{kg}^{-1} \mathrm{DM}\right)$.

\begin{tabular}{|c|c|c|c|c|}
\hline \multirow[b]{2}{*}{ Specification } & \multicolumn{3}{|c|}{ Silage } & \multirow[b]{2}{*}{ S.E.M } \\
\hline & $\begin{array}{c}\text { Red clover } \\
n=4\end{array}$ & $\begin{array}{c}\text { Alfalfa } \\
n=4\end{array}$ & $\begin{array}{l}\text { Grass } \\
n=4\end{array}$ & \\
\hline Dry matter $\left(\mathrm{g} \cdot \mathrm{kg}^{-1}\right.$ fresh matter $)(\mathrm{DM})$ & $420.7^{\mathrm{A}}$ & $359.8^{\mathrm{B}}$ & $413.5^{\mathrm{A}}$ & 15.51 \\
\hline Organic matter $(\mathrm{OM})$ & $904.7^{\mathrm{A}}$ & $906.5^{\mathrm{A}}$ & $895.4^{\mathrm{B}}$ & 11.21 \\
\hline Crude protein $(\mathrm{CP})$ & $159.9^{b}$ & $167.2^{\mathrm{a}}$ & $155.2^{\mathrm{b}}$ & 6.64 \\
\hline Ether extract (EE) & $14.1^{\mathrm{c}}$ & $20.2^{\mathrm{b}}$ & $25.1^{\mathrm{a}}$ & 2.12 \\
\hline Neutral detergent fibre (NDF) & $509.3^{\mathrm{B}}$ & $462.1^{\mathrm{C}}$ & $590.1^{\mathrm{A}}$ & 13.82 \\
\hline Acid detergent fibre (ADF) & $426.0^{\mathrm{a}}$ & $434.9^{\mathrm{a}}$ & $395.3^{\mathrm{b}}$ & 14.17 \\
\hline $\mathrm{pH}$ & 4.58 & 4.49 & 4.35 & 0.055 \\
\hline Water soluble carbohydrates & 23.5 & 12.1 & 12.3 & 6.1 \\
\hline Ammonia - N (g/kg TN) & $23.4^{\mathrm{b}}$ & $66.4^{\mathrm{a}}$ & $17.5^{\mathrm{b}}$ & 3.42 \\
\hline Lactic acid & $46.3^{\mathrm{B}}$ & $38.1^{\mathrm{C}}$ & $54.2^{\mathrm{A}}$ & 4.22 \\
\hline Acetic acid & $7.3^{\mathrm{B}}$ & $14.0^{\mathrm{A}}$ & $15.4^{\mathrm{A}}$ & 1.12 \\
\hline Butyric acid & 3.2 & 1.4 & 2.1 & 1.19 \\
\hline \multicolumn{5}{|l|}{ Intake (per day) } \\
\hline Dry matter (g) & $519.7^{\text {в }}$ & $645.6^{\mathrm{A}}$ & $528.2^{\mathrm{B}}$ & 25.2 \\
\hline Crude protein (g) & $83.1^{\mathrm{B}}$ & $108.7^{\mathrm{A}}$ & $82.8^{\mathrm{B}}$ & 2.18 \\
\hline Metabolizable energy (MJ) & $5.02^{\mathrm{Ba}}$ & $6.44^{\mathrm{A}}$ & $4.41^{\mathrm{Bb}}$ & 0.22 \\
\hline
\end{tabular}

Means in the same line with different superscripts differ significantly at ${ }^{\mathrm{AB}}(P \leq 0.01)$, ${ }^{\text {ab }}(P \leq 0.05)$, S.E.M standard error of the mean.

The composition of barley meal was $\left(\mathrm{g} \cdot \mathrm{kg}^{-1}\right)$ : DM - 878.3, OM - 856.4, CP - 121.5, EE - 15.5, CF (crude fibre) - 52.6, NDF - 210.1, and ADF - 115.7. Animals were administered with a grain mineral premix in an amount of $12.5 \mathrm{~g} / \mathrm{head} /$ day. The mineral premix contained (\%): calcium carbonate 15.95; sodium chloride 10; magnesium oxide 5; natrium-calcic phosphate and phosphate 1-Ca 4; and carrier up to $100 \%$. 
AOAC (2005), whereas those of NDF (neutral detergent fiber) and ADF (acid detergent fiber) were determined using the method by Van Soest et al. (1991). Silage samples were also assayed for: pH value - with an HI 8314 pH-meter; contents of acids: lactic, acetic and butyric in an aqueous extract - with the method of high-performance liquid chromatography (HPLC) using a Shimadzu apparatus with a MetaCarb 67H column by VARIAN company; content of protein nitrogen (N-protein) - with the method with TCA acid (Licitra et al. 1996); and content of water-soluble saccharides (WSC) - with the anthrone method (Thomas 1977). Table 1 presents results of the analysis of the chemical composition, characteristic of fermentation and nutrient content of silages. The nutritive value of silages was expressed as metabolizable energy (DLG system 1997) according to the below equation:

$\mathrm{ME}=0.0312 \times \mathrm{dEE}+0.0136 \times \mathrm{dCF}+0.0147 \times(\mathrm{DOMD}-\mathrm{dEE}-\mathrm{dCF})+0.00234 \times \mathrm{CP}$ where:

$\mathrm{ME}$ - metabolisable energy (MJ), dEE - digestible ether extract $(\mathrm{g}), \mathrm{dCF}$ - digestible crude fibre (g), DOMD dry organic matter digestible (g), CP - crude protein $(\mathrm{g})$.

The nutritional value of barley was determined according to the DLG table.

Silage samples $(1.0 \mathrm{~kg})$ were collected once before the experiment and $\times 3$ during the experiment. Refusals were collected and weighed daily and pooled into one sample per each 20 days of the experiment. Samples of barley were collected $\times 2$ : before and in the middle of the experiment to determine the mean chemical composition. Silage samples and subsamples of refusals were stored at $-25^{\circ} \mathrm{C}$. After thawing, selected samples were dried at $60{ }^{\circ} \mathrm{C}$ in a Binder dryer, and were ground in a Retsch 200 mill to a particle size of $1 \mathrm{~mm}$.

The fatty acid composition was determined by Gas Chromatography (GC) on a VARIAN CP-3800 chromatograph (Varian Analytical Instruments 2700 Mitchell Drive, Walnut Creek, CA 94598-1675/USA) equipped with a flame ionization detector (FID). Fatty Acid Methyl Esters (FAMEs) were prepared by Peisker's method as modified by Żegarska et al. (1991). The FAMEs were separated using a CP Sil $88(0.20 \mu \mathrm{m})$ capillary column $50 \mathrm{~m}$ long and $0.25 \mathrm{~mm}$ in diameter. The column temperature was $180^{\circ} \mathrm{C}$. Injector and detector temperatures were both $250^{\circ} \mathrm{C}$. Helium carrier gas flow was $1.2 \mathrm{ml} / \mathrm{min}$ at a split ratio of 1:50.

The ram lambs were slaughtered at the following mean body weights in groups: RC $-33.66 \mathrm{~kg}, \mathrm{ALF}-34.69 \mathrm{~kg}$, and GR $-31.75 \mathrm{~kg}$. Samples for meat analysis $(100 \mathrm{~g})$ were collected from the musculus longissimus lumborum removed from the right side of each carcass, after $24 \mathrm{~h}$ cooling of carcasses at a temperature of $4{ }^{\circ} \mathrm{C}$. The following indicators were determined: cholesterol content by the enzymatic method with cholesterol peroxidase (Trinder 1969), using Pointe Scientific tests; and contents of vitamins: A (retinol) and E ( $\alpha$-tocopherol), with the method described by Eriksson and Pickova (2007). The contents of retinol and $\alpha$-tocopherol in extracts were assayed with the HPLC method, using a Nucleosil $\mathrm{C}_{18}$ column $(250 \times 4 \mathrm{~mm})$, in the reversed-phase (RP) system, where a solution of methanol and water $(95: 5, \mathrm{v} / \mathrm{v})$ served as the carrier phase. Retinol content was measured using a UV detector $(336 \mathrm{~nm})$; $\alpha$-tocopherol content was measured with a fluorescence detector (FL, $293 \mathrm{~nm}$, Em 326 $\mathrm{nm}$ ). Fat content was determined, as well. The intramuscular fat content was determined by the Soxhlet method, compliant with PN-ISO 6492:2005, using the device FOSS TECATOR AB (Box 70 S-26321 Hoganas, Sweden). Fatty acid composition in the intramuscular fat was determined with the same method as in silages. Furthermore, values of atherogenic index (AI) and thrombogenic index (TI) were calculated using formulas provided by Ulbricht and Southgate (1991):

$\mathrm{IA}=(\mathrm{C} 12: 0+4 \mathrm{C} 14: 0+\mathrm{C} 16: 0) /($ PUFA n-3 + PUFA n-6 + MUFA $)$

$\mathrm{IT}=(\mathrm{C} 14: 0+\mathrm{C} 16: 0+\mathrm{C} 18: 0) /(0.5$ MUFA + 0.5PUFA n-6 + 3PUFA n-3 + PUFA n-3/PUFA n-6).

The results were processed by one-way ANOVA, and the significance of differences between groups was verified with Duncan's test $(P<0.01$ and $P<0.05)$. Computations were conducted using the Statistica ver. 9.0 software (StatSoft, Inc., USA, 2009).

\section{Results}

A low protein content of the alfalfa and red clover silage resulted from a significantly delayed harvest date (flowering stage of maturity) caused by long-term rainfall. Higher dry matter intake of alfalfa silage resulted from a lower content of NDF, higher DOMD and a lower total content of organic acids (Huhtanen et al. 2002). Speijers et al. (2005) using the same types of silages in the feeding of lambs determined the highest dry matter intake for red clover silage.

The analyzed silages did not differ significantly in the content of saturated fatty acids (SFAs) (Table 2). The greatest contribution in the pool of these acids was noted for C16:0 (palmitic) acid. The silage from alfalfa was characterized by the lowest content of monounsaturated fatty acids (MUFAs) $(P \leq 0.01)$, especially that of C18:1 (oleic) $(P \leq 0.01)$ and C14:1 (myristic) $(P \leq 0.05)$ acids, as well as by the highest content of polyunsaturated fatty acids (PUFAs) $(P \leq 0.05)$. The differences referred mainly to $\mathrm{C} 18: 2$ (linoleic) acid $(P \leq 0.05)$. The lowest contents of PUFAs and C18:2 were assayed in the grass silage.

The analyzed silages had a significant effect on fat and vitamin E contents in the meat of lambs (Table 3). The highest content of fat was assayed in the meat of RC lambs (fed the 
Table 2. Fatty acid composition of silage fat (g/100g fatty acids).

\begin{tabular}{|c|c|c|c|c|c|}
\hline \multirow{2}{*}{ Specification } & & \multicolumn{3}{|c|}{ Silage } & \multirow{2}{*}{ S.E.M } \\
\hline & & Red clover & Alfalfa & Grass & \\
\hline \multirow{7}{*}{$\begin{array}{l}\text { Saturated fatty } \\
\text { acids (SFA) }\end{array}$} & C 12:0 lauric & $0.17^{\mathrm{B}}$ & $0.57^{\mathrm{A}}$ & $0.85^{\mathrm{A}}$ & 0.04 \\
\hline & C 14:0 myristic & $1.03^{\mathrm{b}}$ & $1.14^{\mathrm{b}}$ & $2.00^{\mathrm{a}}$ & 0.09 \\
\hline & C 15:0 pentadecanoic & 1.34 & 1.13 & 1.08 & 0.21 \\
\hline & C 16:0 palmitic & 28.33 & 30.60 & 30.60 & 0.52 \\
\hline & C 17:0 margaric & 0.8 & 0.64 & 0.88 & 0.07 \\
\hline & C 18:0 stearic & 6.41 & 5.01 & 7.85 & 0.11 \\
\hline & Total SFA & 38.08 & 39.09 & 43.26 & 0.56 \\
\hline \multirow{6}{*}{$\begin{array}{l}\text { Monounsaturated } \\
\text { fatty acids (MUFA) }\end{array}$} & C 12:1 lauroleic & 1.39 & 1.21 & 1.26 & 0.06 \\
\hline & C 14:1 myristoleic & $0.37^{\mathrm{a}}$ & $0.20^{\mathrm{b}}$ & $0.20^{\mathrm{b}}$ & 0.05 \\
\hline & C 16:1 palmitoleic & 1.06 & 1.28 & 1.12 & 0.02 \\
\hline & C 17:1 margaroleic & 0.37 & 0.30 & 0.35 & 0.04 \\
\hline & C 18:1 oleic & $15.45^{\mathrm{A}}$ & $6.38^{\mathrm{B}}$ & $15.58^{\mathrm{A}}$ & 0.43 \\
\hline & Total MUFA & $18.64^{\mathrm{A}}$ & $9.37^{\mathrm{B}}$ & $18.51^{\mathrm{A}}$ & 0.37 \\
\hline \multirow{4}{*}{$\begin{array}{l}\text { Polyunsaturated } \\
\text { fatty acids (PUFA) }\end{array}$} & C 18:2 n-6 linoleic & $23.44^{\mathrm{a}}$ & $25.88^{\mathrm{a}}$ & $17.91^{\mathrm{b}}$ & 0.49 \\
\hline & C 18:3 n-3 alpha-linolenic & 19.84 & 25.67 & 20.31 & 0.52 \\
\hline & Total PUFA & $43.28^{\mathrm{ab}}$ & $51.55^{\mathrm{a}}$ & $38.22^{\mathrm{b}}$ & 0.41 \\
\hline & Total UFA & 61.92 & 60.92 & 56.73 & 0.55 \\
\hline
\end{tabular}

Means in the same line with different superscripts differ significantly at ${ }^{\mathrm{AB}}(P \leq 0.01),{ }^{\mathrm{ab}}(P \leq 0.05)$, S.E.M. - standard error of the mean

Table 3. Content of fat, cholesterol and vitamin A and $\mathrm{E}$ in lamb meat.

\begin{tabular}{lcccc}
\hline \multirow{2}{*}{ Specification } & \multicolumn{3}{c}{ Silage } & \multirow{2}{*}{ S.E.M } \\
\cline { 2 - 4 } & Red clover & Alfalfa & Grass & 0.23 \\
\hline Fat $(\%)$ & $3.51^{\mathrm{a}}$ & 2.56 & $2.32^{\mathrm{b}}$ & 4.15 \\
Cholesterol (mg/100g of meat) & 56.09 & 55.91 & 68.69 & 0.02 \\
Vitamin A $(\mu \mathrm{g} / \mathrm{g}$ of meat) & 0.52 & 0.45 & 0.53 & 0.51 \\
Vitamin E $(\mu \mathrm{g} / \mathrm{g}$ of meat) & 3.83 & $2.75^{\mathrm{B}}$ & $6.06^{\mathrm{A}}$ & \\
\hline
\end{tabular}

Means in the same line with different superscripts differ significantly at ${ }^{\mathrm{AB}}(P \leq 0.01),{ }^{\text {ab }}(P \leq 0.05)$, S.E.M. - standard error of the mean

silage from red clover), however, the significance of differences was confirmed only when compared to the GR group $(P \leq 0.05)$. In turn, the meat of GR lambs (fed the silage from grass) showed a higher content of vitamin E. Its content was significantly higher $(P \leq 0.01)$ compared to the meat of ALF lambs (fed the silage from alfalfa).

The silages applied in the study were also found to significantly affect the fatty acid composition of intramuscular fat (Table 4). With regard to saturated fatty acids, the intramuscular fat of the lambs fed the grass silage (GR) was characterized by a higher contribution of C12:0 (lauric) and C14:0 (myristic) acids $(P \leq 0.01)$, and a lower content of C18:0 (stearic) acid $(P \leq 0.05)$, compared to the other groups. In analyzing the unsaturated fatty acids, higher contents of C14:1 (myristoleic) and CLA acids $(P \leq 0.05)$ and the lowest contents of C18:3 (alpha-linolenic) and C20:2 (eicosanoic) acids were determined in the fat of this group of lambs. The content of C18:3 acid was the highest in the fat of RC lambs, 
Table 4. Fatty acid composition of intramuscular fat in musculus longissimus lumborum ( $\mathrm{g} / 100 \mathrm{~g}$ fatty acids).

\begin{tabular}{|c|c|c|c|c|c|}
\hline \multirow{2}{*}{ Specification } & & \multicolumn{3}{|c|}{ Silage } & \multirow{2}{*}{ S.E.M } \\
\hline & & Red clover & Alfalfa & Grass & \\
\hline \multirow{10}{*}{$\begin{array}{l}\text { Saturated fatty } \\
\text { acids (SFA): }\end{array}$} & C 10:0 capric & 0.24 & 0.23 & 0.24 & 0.01 \\
\hline & C 12:0 lauric & $0.34^{\mathrm{B}}$ & $0.33^{\mathrm{B}}$ & $0.49^{\mathrm{A}}$ & 0.02 \\
\hline & C 14:0 myristic & $4.00^{\mathrm{B}}$ & $3.85^{\mathrm{B}}$ & $4.85^{\mathrm{A}}$ & 0.15 \\
\hline & C 15:0 pentadecanoic & 0.56 & 0.51 & 0.59 & 0.02 \\
\hline & C 16:0 palmitic & 28.74 & 28.04 & 28.01 & 0.22 \\
\hline & C 17:0 margaric & 1.43 & 1.36 & 1.32 & 0.03 \\
\hline & C 18:0 stearic & $20.20^{\mathrm{a}}$ & $20.61^{\mathrm{a}}$ & $18.67^{\mathrm{b}}$ & 0.32 \\
\hline & C 20:0 arachidic & 0.15 & 0.18 & 0.15 & 0.01 \\
\hline & C 22:0 behenic & 0.09 & 0.13 & 0.12 & 0.01 \\
\hline & Total SFA & 55.75 & 55.23 & 54.44 & 0.47 \\
\hline \multirow{6}{*}{$\begin{array}{l}\text { Monounsaturated } \\
\text { fatty acids } \\
\text { (MUFA): }\end{array}$} & C 14:1 myristoleic & $0.12^{\mathrm{b}}$ & $0.11^{\mathrm{b}}$ & $0.15^{\mathrm{a}}$ & 0.01 \\
\hline & C 16:1 palmitoleic & 1.26 & 1.25 & 1.32 & 0.03 \\
\hline & C 17:1 margaroleic & 0.96 & 0.96 & 1.03 & 0.02 \\
\hline & C 18:1 oleic & 36.07 & 36.45 & 36.86 & 0.34 \\
\hline & C 20:1 gadoleic & 0.08 & 0.10 & 0.10 & 0.01 \\
\hline & Total MUFA & 38.48 & 38.88 & 39.46 & 0.36 \\
\hline \multirow{8}{*}{$\begin{array}{l}\text { Polyunsaturated } \\
\text { fatty acids } \\
\text { (PUFA): }\end{array}$} & C 18:2 n-6 linoleic & 3.37 & 3.49 & 3.70 & 0.12 \\
\hline & C $18: 2$ cis 9 trans 11 n-6(CLA) & $0.24^{\mathrm{b}}$ & $0.23^{b}$ & $0.28^{\mathrm{a}}$ & 0.01 \\
\hline & C 18:3 n-3 alpha-linolenic & $1.21^{\mathrm{Aa}}$ & $0.98^{\mathrm{b}}$ & $0.93^{\mathrm{Bb}}$ & 0.04 \\
\hline & C 20:2 n-6 eicosanoic & $0.05^{\mathrm{A}}$ & $0.04^{\mathrm{B}}$ & $0.04^{\mathrm{B}}$ & 0.00 \\
\hline & C 20:4 n-6 arachidonic & 0.76 & 0.97 & 1.00 & 0.10 \\
\hline & C 20:5 n-3 eicosapentaenoic & 0.15 & 0.18 & 0.16 & 0.01 \\
\hline & Total PUFA & 5.77 & 5.89 & 6.11 & 0.22 \\
\hline & Total UFA & 44.25 & 44.77 & 45.56 & 0.47 \\
\hline
\end{tabular}

Means in the same line with different superscripts differ significantly at ${ }^{\mathrm{AB}}(P \leq 0.01),{ }^{\mathrm{ab}}(P \leq 0.05)$, S.E.M. - standard error of the mean

and the significance of differences in respect of ALF group was confirmed statistically $(P \leq 0.05)$ and for GR group $(P \leq 0.01)$. The highest content of $\mathrm{C} 20: 2$ acid was assayed in the red clover silage $(P \leq 0.01)$.

The analysis of the fatty acid profile showed that the fat of ram lambs fed the silage from red clover (RC) was characterized by the highest content of polyunsaturated fatty acids of the n-3 family (PUFA n-3) (Table 5). The significance of differences was confirmed statistically, however, only in regard to GR group $(P \leq 0.05)$. The same correlations occurred in the case of the PUFA n-6:PUFA n-3 ratio.

\section{Discussion}

The analysis of traits characterizing the health quality of lamb meat points to different effects of the silages administered to lambs in the fattening period. The silage from red clover was found to enhance intramuscular fat deposition in ram lambs, especially when compared to the silage from grass. Speijers et al. (2005), who used the same types of silages in the feeding of lambs, noted a similar effect in respect of subcutaneous fat that resulted from a higher intake of dry matter of red clover silage and from a higher growth rate of 
Table 5. Fatty acid profile in intramuscular fat, and the atherogenic index (AI) and thrombogenic index (TI).

\begin{tabular}{lcccc}
\hline \multirow{2}{*}{ Specification } & \multicolumn{2}{c}{ Silage } & S.E.M \\
\cline { 2 - 4 } & Red clover & Alfalfa & Grass & 0.01 \\
\hline MUFA:SFA & 0.69 & 0.71 & 0.73 & 0.01 \\
PUFA:SFA & 0.10 & 0.11 & 0.11 & 0.02 \\
UFA:SFA & 0.80 & 0.81 & 0.84 & 0.01 \\
PUFA:MUFA & 0.15 & 0.15 & 0.16 & 0.21 \\
PUFA n-6 & 4.41 & 4.73 & 5.01 & 0.04 \\
PUFA n-3 & $1.36^{\mathrm{a}}$ & 1.16 & $1.09^{\mathrm{b}}$ & 0.20 \\
PUFA n-6:PUFA n-3 & $3.36^{\mathrm{b}}$ & 4.04 & $4.60^{\mathrm{a}}$ & 0.33 \\
DFA (UFA+C18:0) & 64.45 & 65.37 & 64.23 & 0.33 \\
OFA (SFA - C18:0) & 35.55 & 34.63 & 35.77 & 0.03 \\
DFA:OFA & 1.82 & 1.89 & 1.80 & 0.02 \\
AI (atherogenic index) & 1.02 & 0.98 & 1.06 & 0.04 \\
TI (thrombogenic index) & 2.06 & 2.07 & 2.01 & \\
\hline
\end{tabular}

Means in the same line with different superscripts differ significantly at ${ }^{\mathrm{AB}}(P \leq 0.01),{ }^{\mathrm{ab}}(P \leq 0.05)$, S.E.M. - standard error of the mean, SFA - saturated fatty acids, MUFA - monounsaturated fatty acids, PUFA - polyunsaturated fatty acids, DFA - dietary fatty acids having desirable (neutral or hypocholesterolaemic) effect in humans, OFA - dietary fatty acids having objectionable (hypercholesterolaemic) effect in humans

the lambs. In our study, a significantly higher intake of metabolizable energy from the red clover silage might have affected intramuscular fat deposition in lambs of this group. The increase in intramuscular fat content may be negatively evaluated by some consumers, yet when its content is too low it deteriorates the sensory quality of meat. It is noteworthy that this fat was characterized by the highest content of n-3 PUFAs and by the lowest content of n-6 PUFAs, and thereby by the lowest PUFA n-6:PUFA n-3 ratio. Polyenoic acids belong to bioactive substances. They are precursors of eicosanoids: prostaglandins, prostacyclins, thromboxans, leukotrienes, and lipoxins - tissue hormones with a wide spectrum of actions in the body (Simopoulos 2002). Eicosanoids are derivatives of n-6 family fatty acids and are more biologically active; their excess compared to the derivatives of n-3 fatty acids may yield adverse effects on the health status of a body. Hence, it is recommended that the ratio between the quantity of n- 6 and n-3 fatty acids in a diet should be lower than 4 (Wood et al. 2008). In this context, less desirable effects were achieved when feeding lambs the silage from red fescue. In addition, fat of these lambs was characterized by a significant decrease in the concentration of stearic acid (C18:0) reported to express a hypocholesterolaemic effect (Ulbricht and Southgate 1991). It needs to be emphasized, however, that the values of both atherogenic and thrombogenic indices claimed by Ulbricht and Southgate (1991) to be reliable indicators of health risk to consumers, were at a similar level in all groups. When comparing the fatty acid profile of experimental silages and meat of lambs fed with these silages, no directly proportional effect of silage intake was shown on the fatty acid profile of the meat. The intramuscular fat of lambs fed the grass silage was characterized by the highest content of CLA, in spite of the fact that this silage had the lowest content of linoleic acid (C18:2), as the CLA is synthesized in the rumen upon enzymatic biohydrogenation of linoleic acid (Pariza et al. 2001). It may be speculated that this process was linked by the desaturation of trans-11 C18:1 by D9desaturase in animals' tissues (Bauman et al. 2000). The higher content of n-3 PUFAs in the meat of lambs administered the silage from red clover corroborates results of a study by Lee et al. (2009) with cattle. A similar effect, in respect of cow's milk, was achieved by 
Dewhurst et al. (2003). Research done by Simko et al. (2010) suggests that these effects may be due to a low degree of fatty acids biohydrogenation in the rumen and consequently, to a high absorption of n-3 PUFAs in the small intestine. The mechanism relies in, among other things, the inhibition of lipolysis that enables biohydrogenation, and a significant role in this respect is ascribed to polyphenolic oxidase (PPO) known to be very active in red clover (Lee et al. 2008). Protein-phenolic complexes formed as a result of oxidation by PPO are lipase inhibitors, and this consequently impedes the extent of lipolysis in silages and in the rumen. Our study demonstrated a significantly higher concentration of vitamin $\mathrm{E}$ in the meat of ram lambs fed the grass silage compared to silages from papilionaceous plants. A similar effect was reported by Lee et al. (2009) in beef cattle. The contents of some fat-soluble vitamins are also easily manipulated because their contents vary among feeds. Silage can be a good dietary source of $\alpha$-tocopherol, when its quality allows for high levels of $\alpha$-tocopherol consumption (Harstad and Steinshamn 2010). Vitamin E plays a key role in enhancing meat quality. It has been effective in the stability of color and lipids in meat (Arnold et al. 1993). This pertains especially to ruminants, where high vitamin E contents from feeding with grasses prevent oxidation of polyunsaturated fatty acids and stabilize meat color (Wood et al. 2008).

The results of our study indicate that the species of plants used to prepare silage exerts a significant effect on the quality of silage and its intake by lambs. As consequence, it determines nutrient absorption and health-promoting properties of lamb meat.

\section{References}

AOAC 2005: Official Methods of Analysis, $18^{\text {th }}$ edn. Association of Official Analytical Chemists, Washington, D.C., pp. 69-80

Arnold RN, Arp SC, Scheller KK, Williams SN, Schaefer DM 1993: Tissue equilibration and subcellular distribution of vitamin E relative to myoglobin and lipid oxidation in displayed beef. J Anim Sci 71: 105-118

Bauman DE, Baumgard LH, Corl BA, Griinari JM 2000: Biosynthesis of conjugated linoleic acid in ruminants. J Anim Sci 77: 1-15

Dewhurst RJ, Fisher WJ, Tweed JKS, Wilkins RJ 2003: Comparison of grass and legume silages for milk production 1: Production responses with different levels of concentrate. J Dairy Sci 86: 2598-2611

DLG (Deutsche-Landwirtschafts-Gesellschaft) 1997: Feedstuff Tables for Ruminants (in German), $7^{\text {th }}$ edn. DLGVerlag GmbH, Frankfurt, pp. 136-212

Eriksson SF, Pickova J 2007: Fatty acids and tocopherol levels in m. longissimus dorsi of beef cattle in Sweden - A comparison between seasonal diets. Meat Sci 76: 746-754

Fraser MD, Speijers MHM, Theobald VJ, Fychan R, Jones R 2004: Production performance and meat quality of grazing lambs finished on red clover, lucerne or perennial ryegrass swards. Grass Forage Sci 59: 345-356

Harstad OM, Steinshamn H 2010: Cows' diet and milk composition. In: Griffiths M (Ed.) Improving the Safety and Quality of Milk: Milk Production and Processing (Volume 1). Woodhead Publishing Limited, Cambridge, UK, pp. 223-245

Huhtanen P, Khalili H, Nousiainen JI, Rinne M, Jaakkola S, Heikkila T, Nousiainen J 2002. Prediction of the relative intake potential of grass silage by dairy cows. Livest Prod Sci 73: 111-130

Lee MRF, Evans PR, Nute GR, Richardson RI, Scollan ND 2009: A comparison between red clover silage and grass silage feeding on fatty acid composition, meat stability and sensory quality of the $\mathrm{m}$. longissimus muscle of dairy cull cows. Meat Sci. 31: 738-744

Lee MRF, Scott MB, Tweed JKS, Minchin FR, Davies DR 2008: Effects of polyphenol oxidase on lipolysis and proteolysis of red clover silage with and without a silage inoculant (Lactobacillus plantarum L5). Anim Feed Sci Technol 144: 125-136

Licitra G, Hernandez TM, Van Sjest PJ 1996: Standardization of procedures for nitrogen fractionation of ruminant feed. Anim Feed Sci Technol 57: 347-358

Lourenço M, De Smet S, Raes K, Fievez V 2007: Effect of botanical composition of silages on rumen fatty acid metabolism and fatty acid composition in longissimus muscle and subcutaneous fat of lambs. Anim Feed Sci Technol 1: 911-921

Lourenço M, Van Ranst G, Vlaeminck B, De Smet S, Fievez V 2008: Influence of different dietary forages on the fatty acid composition of rumen digesta as well as ruminant meat and milk. Anim Feed Sci Technol 145: 418-437

Pariza MW, Parka Y, Cook ME 2001: The biologically active isomers of conjugated linoleic acid. Prog Lipid Res 40: $283-298$ 
PN-ISO 6492: 2005 Animal Feeding Stuffs - Determination of fat content, Polish Committee for Standardization. Poland, 20 April 2005: 1-14

Šimko M, Čerešňáková Z, Biro D, Juráček M, Gálik B, Strakova E, France J, Alzahal O, McBride B 2010: Influence of wheat and maize starch on fermentation in the rumen, duodenal nutrient flow and nutrient digestibility. Acta Vet Brno 79: 533-541

Simopoulos AP 2002: Omega-3 fatty acids in inflammation and autoimmune diseases. J Am Coll Nutr 21: 495-505

Speijers MHM, Fraser MD, Theobald VJ, Haresign W 2005: Effect of ensiled forage legumes on performance of store finishing lambs. Anim Feed Sci Technol 120: 203-216

Thomas TA 1977: An automated procedure for the determination of soluble carbohydrates in herbage. J Sci Food Agr 28: 639-642

Trinder P 1969: Determination of glucose in blood using glucose oxidase with an alternative oxygen acceptor. Ann Clin Biochem 6:24-27

Ulbricht TLV, Southgate DAT 1991: Coronary heart disease: seven dietary factors. The Lancet 338: $985-992$

Van Soest PJ, Robertson JB, Lewis BA 1991: Methods for dietary fiber, neutral detergent fiber and nonstarch polysaccharides in relation to animal nutrition. J Dairy Sci 74: 3583-3597

Wood JD, Enser M, Fisher AV, Nute GR, Sheard PR, Richardson RI, Hughes SI, Whittington FM 2008: Fat deposition, fatty acid composition and meat quality: A review. Meat Sci 78: 343-358

Ząbek K, Milewski S, Wójcik R, Siwicki AK 2013: Effect of $\beta$-1,3/1,6-D-glucan in diet on productivity and humoral and cellular defense mechanisms in sheep. Acta Vet Brno 82: 141-146

Żegarska Z, Jaworski J, Borejszo Z 1991: Evaluation of the modified Peisker method to obtain fatty acid methyl esters. Acta Acad Agric Technol Olst 24: 25-33 